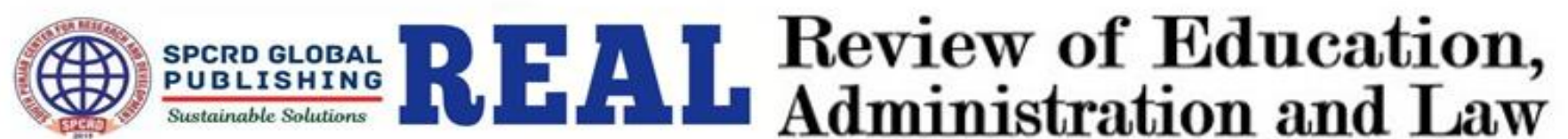 \\ Journal homepage: http://real.spcrd.org ISSN (Print): 2708-1788 ISSN (Online): 2708-3667
}

\section{Exploring the Construal of Cultural Hybridity in the Maps for Lost Lovers: A Discourse Stylistics Study}

\author{
${ }^{a}$ Muazzma Batool, ${ }^{b}$ Tazanfal Tehseem, ${ }^{c}$ Rabia Faiz \\ ${ }^{a}$ Research scholar at the department of English, University of Sargodha, Pakistan \\ Email: muazzmab@gmail.com \\ ${ }^{\mathrm{b}}$ Assistant Professor at the department of English, University of Sargodha, Pakistan \\ Email: tazanfal.tehseem@uos.edu.pk \\ ${ }^{\mathrm{c}}$ Lecturer at the department of English, University of Sargodha - Pakistan \\ Email: rabia.faiz@uos.edu.pk
}

\begin{tabular}{|c|c|}
\hline $\mathbf{A R}$ & \multirow{10}{*}{$\begin{array}{l}\text { ABSTRACT } \\
\text { This study undertakes an analysis of hybrid discourse with the help of } \\
\text { discourse stylistics, an approach to the study of literary texts which } \\
\text { combines findings from the fields of discourse analysis, conversation } \\
\text { analysis and pragmatics. The analysis aims at highlighting how the } \\
\text { cultural hybridity which exists in characters is manifested by the } \\
\text { linguistic organization of the exchange as interactive process. The study } \\
\text { based on cultural hybridity in hybrid discourse shows that the } \\
\text { characters ignore their respective position while interaction because } \\
\text { both children and parents treat each other as equal sometimes by } \\
\text { scorning, criticizing, satirizing, questioning and sometimes by } \\
\text { manipulation to foreground their hybrid culture. }\end{array}$} \\
\hline His & \\
\hline & \\
\hline & \\
\hline Кеу & \\
\hline $\mathrm{Hybr}$ & \\
\hline 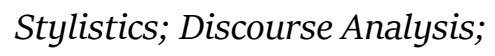 & \\
\hline Con & \\
\hline Pragi & \\
\hline L & \\
\hline
\end{tabular}
I21, I2O

(C) 2020 The authors. Published by SPCRD Global Publishing. This is an

DOI: $10.47067 /$ real.v3i2.46 open access article under the Creative Commons AttributionNonCommercial 4.0

Corresponding author's email address: muazzmab@gmail.com

\section{Introduction}

The focus of this study is to highlight cultural aspects in the 'Maps for Lost Lovers' by applying Discourse Stylistics Approach (Carter and Simpson, 1989). Since language plays a crucial role in disseminating particular ideologies; therefore, in Discourse Stylistics Approach (Carter and Simpson, 1989) the efforts to explore and expose the cultural hybridity (Bhabha, 1994) highly depend on discourse analysis and pragmatics. The data for this study comprise 20 exchanges, 151 clauses and 1,010 words.

The present study of cultural hybridity in the hybrid discourse arises from the belief that "language is essentially a social phenomenon" (Kress, 1985a, p.1, as cited in Calvo, 1990) and that "all social interactions involve displays of power" (ibid). The junction of these two convictions is therefore 
central to this study: since power relations are present in most social encounters to negotiate the roles between characters to highlight their hybrid nature and language plays an important part in social interaction.

Searle's (1976) model of speech act theory has tried to indicate that linguistic choices can be used to reject, assert and negotiate social identities and, as a result, contribute to preserve or change power relations. Together with Searle's framework, the model for the analysis of Cooperative Principle developed by Grice (1975) suggests that linguistic choices are involved in stating inequalities in social prestige. This research paper has been implemented to answer the following research questions.

- How does cultural hybridity in the novel contribute to the reproduction of ideology?

- How does portrayal of identity crises impact on the overall grooming of characters?

\section{Literature Review}

The purpose of this section is to review what work has been carried out in the 'Maps for Lost Lovers', cultural hybridity and the work that inspires Discourse Stylistics. A discourse stylistics analysis seeks to disclose the sorts of meaning which would evade traditional meaning of stylistics. It further attempts to unlock the social relations embedded in a text (Carter and Simpson, 1989). In view of Bhabha (1994), cultural hybridity concerns with a new culture which is the result of fusion of diverse cultures.

Devika (2016), Karima (2013) and Zubair (2012) foregrounded hybrid cultures and hybrid identities in their studies. Saini (2015), Parmar (2015) and Singh (2015) examined their studies in the light of feminine perspective and observed that women are subjugated both by society and family. Phompun, Thongthew\&Zeichner (2013) attempted to identify student teachers' new method of teaching using Bhabha's concept of hybridity in Chulalongkorn University, Bangkok, Thailand and found out that student teachers have adopted new teaching identities after getting insight from university professors and cooperating teachers. Karanja (2010) highlighted Kenyan urban youth's hybrid language called 'Sheng' using Bhabha's concept of Hybridity.

It has been recognized by Magu (2015) that the effect of Globalization permeates local cultures because the cultures have the ability to be dynamic and adaptive. Naranjo (2008) attempted to demonstrate the cultural hybridity in three canonical Chicano novels with the help of the characters of Antonio, a boy (lack of name) and Becky. Zaidi and Qureshi (2013), Silima (2013), Shirazi (2014) and Mashori and Zaib (2015) explored the oppression of females in male chauvinistic society. Adinkrah (2013) examined the African culture of two postcolonial novels by Chinua Achebe and Elechi Amadi that protagonists of both novels commit suicide in the same way whereas their societal norms consider it bad.

Qadha (2013) applied discourse stylistics approach in his study and found that Lawrence attempts to express his anger to his reader. Emecheta's rhetorical style is highlighted through Systemic Functional Approach (Opara, 2014). Ajmal (2014) attempted to highlight fake poets in his study premised on stylistics and discourse analysis. Premised on pragmatic stylistics and discourse analysis as a theoretical framework, Abushihab (2015) opined that one could discover the fore coming outcome through context of a particular event. Osisanwo (2013) observed three different fields of tenor in three selected extracts in the research built on the theoretical framework of Politeness Principle. Antony (2014) attempted to identify cohesive markers in a text through discourse stylistics analysis. Bayat 
(2013) interpreted speech acts through content analysis and highlighted that the act of thanking, apologizing and refusing were expressed in an explicit way while the act of complaining is performed implicitly.

Waterman (2010) highlighted modernity and cultural trauma in the light of Shamas, Kaukab, Suraya, Jugnu, Chanda, Barra and Mah-Jabin's characters. Yaqin (2013) foregrounded nostalgia and loneliness of some characters in her essay by comparing Faiz Ahmed Faiz's'Dasht- e-Tanhai' with Aslam's'Maps for Lost Lovers' through Appiha's terminology of partial cosmopolitanism and Brenann's cosmo-theory. Moore (2009) disclosed terror and identities of characters after 9/11 by using Judith Butler's view of terror in one study. Weingarten (2011) exposed intersections of gender and religious identities in novel through the light of Kaukab, Shamas, and Suraya's characters. Amer (2012) illustrated unspeakability of subaltern people like Kaukab by applying Spivak's view on subaltern people and concluded that although undermined masses can speak at one time but still remain subverted on the other.

This study is significant in the respect that the analysis of the selected exchanges will delineate cultural hybridity (Bhabha, 1994) and identity crises of immigrants. It will contribute significantly to the research in the field of cultural and discourse analytical studies as it will bridge the existing gap between the former studies and this particular one. It will open up avenues in research on similar other literary texts and help in inspiring researchers to uncover hidden ideologies through various perspectives used in this approach.

\section{Theoretical Background of the Study}

Discourse stylistics (Carter and Simpson, 1989) provides the benefits of an eclectic methodology as well as the analysis with a sense of direction. It can also make a link between linguistics and literary studies by avoiding some of the shortcomings of both disciplines and meeting some of their requirements. Because of its interest in the internal organization of texts and in suprasentential analysis, discourse stylistics (ibid) can go beyond the mere descriptivism of traditional linguistic stylistics and into the evaluation and interpretation of literary texts. It (ibid) tackles a number of theories to uncover the meaning of a single text. Since Discourse stylistics analysis can take into consideration a number of theories, therefore, the analysis of the present study has been conducted at Grice's conversational maxims (1975) and Searle's model of speech act theory (1976).

\subsection{Grice's Cooperative Maxims}

Grice (1975, as cited in Levinson, 1983) develops a theory which deals with the usage of language by the people. In this theory, he (ibid) formulates the concept of implicature and indicates that there is a set of predominant assumptions guiding the behavior of conversation and for these guidelines he (ibid) identifies four basic maxims of conversation which jointly express co-operative principle. They define the order that how participants have to converse in a maximally rational, co-operative and efficient way. These maxims are as follows:

\subsubsection{The Co-operative Principle}

For him (ibid), the co-operative principle puts:

“... make your contribution such as is required, at the stage at which it occurs, by the accepted purpose or direction of the talk exchange in which you are engaged”

\subsubsection{The Maxim of Quality}

Grice (1975, as cited in Levinson, 1983) 
This maxim puts that try to make your contribution true, particularly:

1) Do not say what you believe is not true and 2) do not say anything for which you do not have adequate evidence

\subsubsection{The Maxim of Quantity}

This maxim says that 1) make your contribution as informative as is required for the present aim of the exchange and 2) do not make your conversation as more informative as is needed

\subsubsection{The Maxim of Relevance}

The relevance maxim explains that your contribution must be relevant.

\subsubsection{The Maxim of Manner}

This maxim gives importance to be precise, brief and ordered during exchange and further says that obscurity and ambiguity should be avoided.

\subsubsection{Speech Act Theory}

Speech act theory concerns with the effect of utterances on the behavior of speaker and hearer (Crystal, 1997).

\subsubsection{Speech Act Theory (John Searle's Model, 1976)}

Searle (1969, p. 18, as cited in Levinson, 1983) puts "anything that can be meant can be said". He (1976, as cited in Levinson, 1983) further distributed illocutionary acts into five types of utterance such as:

- $\quad$ Representative speech act deals with the manifestation of true proposition made by speaker e.g. affirm, report, concluding, asserting, believe, etc.

- Directive speech act talks about the endeavors by speaker to get the audience to do something e.g. through requesting, questioning, commanding, insisting, challenging etc.

- Commissive speech act concerns with the attempts made by the speaker for future course of action e.g. threatening, offering, pledging, promising, swearing, guarantee, vowing etc.

- Expressive speech act expresses the psychological state of mind of the speaker. For instance, by welcoming, thanking, thinking, congratulating, condolence, deploring, apologizing etc.

- Declarative speech act tends to explore the immediate change in the environment by making an utterance e.g. declaration of war, excommunication etc.

\section{Data Analysis and Interpretation}

The Cooperative Principle (Grice's model, 1975) and Speech Act Analysis (Searle's framework, 1976) have been applied on the hybrid discourse to analyze the transformed or hybrid culture of the Pakistani born immigrants, living in Britain, through their conversation in terms of exchanges.

\subsection{Analysis of Exchange One}

Kaukab expresses her astonishment after hearing her son's vasectomy "A vasectomy! You've had a vasectomy!"(Aslam, 2012, p. 81) and questions to him "When did you have it done?” (ibid). She does not know what she should say because her son has become hybrid under his British wife's culture. She expresses her regret. Charag responds her in a shameless way that he has have vasectomy " $A$ while back."(ibid) and tells his mother in an authoritative way that he does not want any more children ever as neither he can look after them properly, nor he has time for doing so using expressive, declarative 
and representative speech acts. Charag, in responding to his mother's question, follows all maxims of Cooperative Principle except the maxim of Quantity in its one sense as he says more than needed. He exerts his power over his mother in the same way as what Saini (2015) demonstrates the situation of Ammu, Rahel and Baby Kochamma in a patriarchal society (For reference, see Literature Review).His utterance towards his mother in an authoritative way and his act of vasectomy take him away from his culture and he becomes hybrid.

\subsection{Analysis of Exchange Two}

Kaukab follows all maxims of Cooperative Principle while questioning to her son's bad action while Charag violates the maxim of Quantity in a manner that he speaks less than required. Only directive speech act has been used twice once by Kaukab and once by Charag. She questions to her son that how could he make "such a big decision without first consulting" (Aslam, 2012, p. 82) his parents. But unlike her wishes, Charag questions to her again "What?" (ibid) showing at one hand that he has not heard her what she has said. On the other hand, his question indicates that he is scorning at his mother's longings (that what she is saying and how she can involve in his personal life) as Papoo, Ayah and other female characters have been treated by men in a study made by Parmar (2015), (For reference, see Literature Review).Thus, Charag's way of reply indicates his hybrid culture as his mother does not have any importance in his life anymore and he wants to be free from all clutches of her Islamic rules and regulations as well as his mother and does not want to respect his parents.

\subsection{Analysis of Exchange Three}

In this exchange, Kaukab observes all maxims of Cooperative Principle while replying to Charag's question who pretends as if he has not understood what his mother has said or he does not want to listen to her attentively. On the other hand, Charag breaks up the maxim of Quantity and says less than required whereas he follows the rest of maxims. It has been highlighted that Charag in responding to Kaukab's question, that “...why couldn't you have been just careful, instead of doing something as drastic as that?” (Aslam, 2012, p. 82), informs his mother that the first son he got “...was an accident" (ibid) using representative speech act.

Thus, the violation of the maxim of Quantity, Charag's usage of directive and representative speech acts and his stubbornness for committing vasectomy and considering it a good act show that his culture has become hybrid and he does not bother to reply exactly to his mother and states something else to cut this matter off. He neither wants his mother's involvement in his personal matters, nor wants to fulfill his religious norms as what Magu (2015) explained in his study that under the effect of globalization the local cultures get changed (For reference, see Literature Review).

\subsection{Analysis of Exchange Four}

Kaukab ignores the maxims of the Quantity and Manner in their first sense as she utters more than needed and disrupts the precision of her conversation whereas the rest of the maxims have been observed. She breaks these maxims to show her authority in her cultural manner in one sense while her culture too becomes hybrid within the passage of time on the other hand as she speaks to her son about his sexual matter without feeling any shame and without hesitating about what she utters when she asks “Really? It wasn't planned?” (Aslam, 2012, p. 82). She tries to exert power over her son but in spite of her utmost try fails to do so as what Singh (2015) explains the catastrophe of females in the light of Bapsi Sidhwa's female characters such as: Zaitoon, Feroza, Ayah, Papoo, Ranna and Putli, (For reference, see Literature Review).

Following all of the maxims of Cooperative Principle, Charag flouts the maxim of Quantity at one 
sense because he does not bother himself to answer his mother's questions and says instead less than needed for the current situation to cut the matter off. He begs forgiveness from his mother in an ironic manner, "I am sorry, but I can't listen to any more of this" (Aslam, 2012, p. 82), so that she may leave this topic anymore and in this way, his hybrid culture has been highlighted that he has no feelings, respect and space in his heart for his Islamic culture and behaves to his mother in Western ways. Kaukab taunts that sometimes she thinks that his wife (Western girl) trapped him for getting pregnant using directive and expressive speech acts.

\subsection{Analysis of Exchange Five}

Here, Kaukab consults Chanda to repent for her sin as she is committing sin while living with Jugnu without NIKAH and without being divorced from her husband and threatens her about the Judgement Day that she will not be able to get forgiveness by God at that time following representative speech act "If truly offered, repentance is honoured" (Aslam, 2012, P. 87-88) but Chanda is not ready to listen to her advice and religious terms and conditions. She declares that "There is no alternative." (ibid) for their union as neither she is divorced from her husband, nor he can be located to divorce her and in this respect, they will live together in a natural way as they "love each other deeply and honestly" (ibid). Chanda ignores the maxims of Quantity and Manner at one level as she utters more in a disordered manner whereas the rest of the maxims have been taken into account. She breaks up with these maxims to break up with her own Pakistani and Islamic culture. Similar to Tehmina Durrani's oppression against her husbandforegrounded by Zaidi and Qureshi (2013) (For reference, see Literature Review),.this all indicates that Chanda's outspoken way of utterance and her decision to live with Jugnu in sin show her hybrid culture.

\subsection{Analysis of Exchange Six}

All maxims of Cooperative Principle have been observed in this exchange. Kaukab answers to Chanda's previous evidences to live with Jugnu and tries to assert herself saying "I care about what it is, yes, but also about what it looks like.” (Aslam, 2012, p. 88). Kaukab responds Chanda in an authoritative manner using representative speech act but Chanda, unlike Kaukab's expectations of getting positive response, illustrates that she cares "only about what it is" (ibid) (because she and Jugnu love each other) and she will live with Jugnu, no matter this is good way or bad one. Chanda comments in an angry mood using representative speech acts to show that she does not accept her will to break up her relation with Jugnu.

The above discussion attempts to show that Chanda's obstinacy for committing the sin and her conduct towards elders in Pakistani context make her hybrid at one hand whereas on the other hand, Kaukab's adoption of strict manner for Chanda and Jugnu's separation according to Islamic laws takes her away from her culture because in Islam, coercion (to convince someone for a good thing by forcing him/her) is prohibited. Chanda becomes hybrid by violating her religious and social norms as what Devika (2016) (For reference, see Literature Review) fore grounds the religious violation of Rahel and Ammu.

\subsection{Analysis of Exchange Seven}

Kaukab breaches the maxims of the Quantity and Manner in their first sense because she utters in an imprecise manner to assert her authority over her children whereas the rest of the maxims have been taken into account. Mah-Jabin, in her turn, obeys all maxims of Cooperative Principle but she makes lame excuses in an ironic manner to stop the topic and her mother's advices. It has been shown that Kaukab becomes angry because of Mah-Jabin's interruption in her mother's conversation before completion of her turn. Her anger has been expressed through expressive and directive speech acts: 
expressive because of her irritation on Mah-Jabin's usage of "oh Christ” (Aslam, 2012, p. 145) and interruption in her mother's utterance; and directive because of her authoritative questions to MahJabin that "You had been quiet for a while so I was just making conversation" (Aslam, 2012, p. 144). Mah-Jabin, on the other hand, uses expressive speech act while bidding sorry to her mother in a sarcastic way at one hand and telling her about her uncle Jugnu's usage of these words (oh Christ), on the other hand. This shows that not only Mah-Jabin, but other family members too have lost their culture because of their stay in Britain like Feroza and Changez's because of their stay in America as demonstrated by Zubair (2012), (For reference, see Literature Review).

\subsection{Analysis of Exchange Eight}

In this exchange, Mah-Jabin takes into consideration all the maxims of Cooperative Principle except the maxim of Quantity and Manner at their first level. She questions her parents' authority in a rude and impolite way and answers her mother's questions in an ill-mannered way. Kaukab forbids her not to go to America and adds further that “I'm sure your father wouldn't approve either" (Aslam, 2012, p. 157). Mah-Jabin responds her in an outburst way that she will not skip her visit as she is fed up with her own type of people and now will "try a strange country full of strangers this time" (Aslam, 2012, p. 158)and adds further that she is "not afraid of Father" (ibid) and will do what she wants to do. This shows that she wants to decide her matters of life herself and does not want her parents to bother her while interfering in her personal matters. All the above discussion indicates Mah-Jabin's hybrid culture where there is no place for purity anymore like Chicanos who lost their pure culture because of the involvement of the Anglo-American and the Mexico traditions as mentioned by Naranjo (2008), (For reference, see Literature Review).

\subsection{Analysis of Exchange Nine}

In this exchange, Mah-Jabin utters against her mother as much as she can, calling her a "moral cripple” (Aslam, 2012, p. 161). She is too outspoken who does not care about her mother's emotions and sentiments. She speaks to her as if she is speaking to an age fellow girl while throwing her anger and demanding answers her questions "Answer me ... Answer me ..." (ibid). She takes her mother responsible for the difficulties in her life as it is her mother who marries her in Pakistan and then again convinces her to go back to her husband without caring the bad deeds her husband has done to her. She criticizes her mother's rules and regulations which are responsible for the hardships in Mah-Jabin's life. She wants to repress the male authority openly (violating her cultural norms) as she belongs to second generation just like Ammu, Rahel, Laila and Mariam as identified in a study by Silima (2013), (For reference, see Literature Review).

It has been explained that Kaukab follows only the maxim of Relevance while the rest have been disrupted by her because she does not know what to say to her daughter. She is confused about her daughter's ill-mannered conduct. There is disordered, impreciseness and ambiguity in Kaukab's answer (who wants her children to be good mannered and here every word of Mah-Jabin goes against her mother's expectations) “Get away from me, you little bitch!” (Aslam, 2012, p. 162).

\subsection{Analysis of Exchange Ten}

Kaukab asks about her daughter's authority that "How dare you throw questions at me like stones!"(Aslam, 2012, p. 162) and Mah-Jabin, losing her culture, responds her by taking Pakistani culture responsible for Chanda and Jugnu's murder. She says to her mother that Pakistani people have taken their "laws and codes, the so-called traditions"(Aslam, 2012, p. 163) with them which have no justice and supports and force people to commit someone's murder. She says what comes in her mind against Pakistani culture and her mother using expressive speech act. 
This exchange indicates that Mah-Jabin flouts the maxims of Quantity as she speaks more than needed; the maxim of Manner as there is no precision and order in her utterance; and the maxim of Relevance whereas the rest have been considered by her. She disrupts these maxims because instead of responding to her mother's question she tries to give evidence to prove herself. She speaks against her religious and cultural notions and supports Chanda and Jugnu's illicit relation.

Kaukab remains lifeless before her daughter thinking that her own child is throwing questions and talking to her in a rude way. Mah-Jabin does not care about her mother's feelings. The rude attitude of Mah-Jabin towards her mother shows that she has breached from her own culture where there is the element of respect for parents. She deviates from her culture in a way as Kenyan urban youth make a hybrid language (Sheng) highlighted by Karanja (2010), (For reference, see Literature Review).

\subsection{Analysis of Exchange Eleven}

It has been examined in this exchange thatKaukab tries to relax Mah-Jabin's resentment about her troubles in life saying that she is sorry if she becomes angry seeing the knife in her mother's hand as she does not know that she has it while talking to her. But in spite of silencing Mah-Jabin, she bursts more than before about her mother's attitude and her religion. She says that her mother wants her to go back to Pakistan to her "earthly god" (Aslam, 2012, p. 163) just as Chanda's parents want. She, further, adds that Chanda's parents married her twice or thrice and when she wishes to live with Jugnu without their permission they killed her. For her, her mother has the same wishes for her to go back to Pakistan to her husband to satisfy herself according to her culture. She shouts at her mother during utterance using directive and expressive speech acts and showing her hybrid culture. Her hybrid identity can be compared to that of Kurtz and Sierva illustrated by Karima, 2013, (For reference, see Literature Review).

Mah-Jabin bears in mind the maxims of Quality, Relevance and Quantity and Manner at their second level while the last two have been disregarded in first sense. The violation of these maxims indicates her breakage from her own culture as she speaks in an imprecise way to her mother. She shakes her mother's sentiments and does not bother herself for excuse even rather speaks as much as she can. She discourses that the laws of Pakistani culture are not good because there is no status for women. Men want to treat women in their own way without respecting their thoughts. In such a chauvinist culture, women become puppet in the hands of men and society who do not permit them to be free to choose their partner themselves. She breaks with Pakistani culture to be free from all these laws.

\subsection{Analysis of Exchange Twelve}

Here, Kaukab takes into account all maxims of Cooperative Principle while answering to her daughter's questions because she wants her daughter to be a Pakistani and to respect Pakistani culture whereas Mah-Jabin contravenes the maxims of Quantity and Manner in their first sense considering the rest maxims. She speaks in a rude and blunt way saying "Don't lie"(Aslam, 2012, p. 164). She commands her mother "don't come near me I said" (ibid) as she cannot accept her desire to go back to Pakistan to her husband. She denies her marriage as she is not happy with her husband and does not want to go back to him. Her repudiation from marriage and way of talking to her mother illustrates her away from her culture.

Kaukab directs Mah-Jabin that she does not "have the freedom to give you that freedom" (ibid) to go to America but Mah-Jabin responds that she can do so if she wants. She says that actually her mother 
wants her to go back to Pakistan to her husband this is why she is making lame excuses. Mah-Jabin's culture becomes hybrid because of her conduct towards her mother which she makes using directive, representative and expressive speech acts. Her way of alienation from her culture, especially from her husband, can be compared to Tehmina Durrani's violation as identified by Zaidi and Qureshi (2013), (For reference, see Literature Review).

\subsection{Analysis of Exchange Thirteen}

In this exchange, Kaukab violates the first levels of the maxims of Quantity and Manner to throw her anger over her daughter and speaks as much as she can whereas the rest of the maxims have been considered. She breaks up her silence and answers Mah-Jabin's all questions (current and previous) in this utterance. She wants her daughter to respect her cultural norms, to go back to her husband and teaches her with affection on one hand while with anger on the other. She is proud to be a Muslim and Pakistani and says proudly to her daughter that her "religion is not the British legal system, it's Islam" (Aslam, 2012, p. 164)and she cannot divorce her husband under British system if she does so she will not be divorced in the eyes of Islam and will be his wife as long as he does not divorce her. To cut the matter off, Mah-Jabin follows all maxims of Cooperative Principle but still she utters in a sarcastic, ironic and angry manner to show her breakage from her own culture. Her rude behavior indicates that she needs independence and wants to do every possible thing.

Kaukab responds her previous question that when she told her about marriage life that two decades of life belongs to husband while rest to the wife then her mean is not to make a bad situation after marriage where your children have to support you against their father. She adds that her purpose was just to clear her daughter about such conditions. Then she says that her purpose was not to harm her taking a knife to her while talking. Kaukab tries to justify herself through representative, expressive and directive speech acts. But Mah-Jabin scorns her mother through expressive speech act that "it's not the first beating I've taken from you" (Aslam, 2012, p. 165). She tells her mother in a sarcastic manner that she beats her children after getting beaten by her husband. Actually, she wants to remind her about the chauvinist society in Pakistan where women have no rights. She transforms her culture like student teachers in Chulalongkorn University, Bangkok, Thailand who make their way of teaching hybrid what Phompun, Thongthew \& Zeichner (2013)(For reference, see Literature Review) discussed in their study.

\subsection{Analysis of Exchange Fourteen}

Mah-Jabin ignores the maxim of Quantity in its second sense as she speaks less than required to the present situation whereas the rest of the maxims have been observed. She violates the maxim of Quantity because she is shocked to hear her brother and it seems that he has completely lost his senses while talking to his mother and sister. Ujala's hybrid culture has been highlighted by the use directive speech act while questioning to his mother and sister in a rude way when he asks them "Would one of you stop licking the other's pussy for a second” (Aslam, 2012, p. 430) which is inappropriate in Pakistani context where there is an aspect of respect for mother and sister which he has lost. His culture has become hybrid as he has no sense of his blood relations. His sister does not know what to say to him and Kaukab too has become nervous and unable to reply him. Not knowing what to say, Mah-Jabin expresses her anger and astonishment calling him “Ujala!'” (ibid). Kaukab's yearnings have been totally damaged through her child's behavior towards her. She becomes lifeless and silent. Ujala's conduct towards his mother and sister indicates that he has become hybrid as Aliya and Mariam who violate their cultural norms marrying with low caste people unlike their tradition, Shirazi (2014), (For reference, see Literature Review).

\subsection{Analysis of Exchange Fifteen}


Here, Kaukab does not take into consideration the second part of the maxim of Quantity whereas she follows the rest because she is annoyed at Charag's behavior who speaks in a vulgar manner to his mother while showing his picture he has made. Charag's reaction towards his mother in the picture depicts his hybrid culture who feels no shame while displaying such shameful matters in his art. Frustrated from Ujala and Mah-Jabin's behavior, Kaukab wants to get relax but her elder son wants to fulfill his desire for torturing his mother displaying his portrait before her. The more she tries to get the chance of relaxation, the more her children interrupt to tease her. He sketches his mother, in his family portrayal, as a pregnant lady and using directive speech act asks her "How pregnant were you then, Mother?"(Aslam, 2012, p. 453). His rude attitude aggravates his mother who calls him vulgar. Kaukab becomes the puppet in the hands of fate and feels destruction inwardly which highlights cultural hybridity in Charag's character.

\subsection{Analysis of Exchange Sixteen}

Shamas cannot see and bear his wife's present condition (who has become wretched after a long trial made by her children) and wants to lessen his wife's torture by changing the topic of conversation saying that in view of Western doctors "It is healthy to have a boy circumcised" (Aslam, 2012, p. 457)using expressive speech act. Ujala interrupts and wants to check his mother's expressions and point of view about circumcision directing her whether they will stop circumcising if these doctors oppose it. Like Ujala's expectations, Kaukab abruptly and ferociously responds "Of course not" (ibid) which shows that the unspeakable too can speak in postcolonial era as Younis speaks in a study by Mashori and Zaib (2015), (For reference, see Literature Review). Ujala's pigheadedness to destroy his mother illustrates his hybrid culture. He fulfills all maxims of Cooperative Principle questioning to his father's point of view and especially to know the point of his mother to have another chance to mock at her sentiments. She wants her children to be away from such acts but they involve in them as much as she tries to detach them.

\subsection{Analysis of Exchange Seventeen}

Mah-Jabin interrupts to support her mother in a satiric way and to stop Ujala's shouting "Be quiet, Ujala, please” (Aslam, 2012, p. 460) following all maxims of Cooperative Principle and directive and expressive speech acts. While answering to Ujala's utterance, she patronizes her mother that she feels shame speaking to others and going back from the four walls of her house because "she is not sure whether she can count on a friendly response" (ibid). Ujala cannot understand Mah-Jabin's taunt and orders her not to make such pretension to relief her from his clutches. He violates the first levels of the maxims of Quantity and Manner following the rest of the maxims because he criticizes her actions in an imprecise manner to show that she has neither any achievement in England, nor in Pakistan. His shouting has been expressed through expressive and directive speech acts. Thus, the criticism made by both Mah-Jabin and Ujala towards their mother indicates their hybrid culture.

\subsection{Analysis of Exchange Eighteen}

In this exchange, Ujala again questions to his mother to know her point of view about the murder of his uncle Jugnu and his beloved Chanda in a cynical way that whether she favors the manipulative group or shows her disgust for them saying that "But were they dirty unclean sinners?" (Aslam, 2012, p. 460). Whereas its second interpretation can be to tease his mother for reminding about the manipulative group Charag has condemned. His usage of directive speech act while bantering at his mother reveals his cultural hybridity. Kaukab observes all maxims of Cooperative Principle and directive speech act while answering to her son that he is wrong if he thinks that she will ignore their murder. Ujala's ridiculing attitude takes him away from his culture. 


\subsection{Analysis of Exchange Nineteen}

The more Kaukab tries to take her son into confidence, the more he becomes rough, questions her authority and makes her every attempt (to comfort him) fail. Ujala again questions in a disgusting manner about Chanda and Jugnu's murder losing his pure culture and Kaukab responds him in a more precise way flouting the maxim of Quantity at its second sense. Her respond shows that she has been tired of this quarrel now and does not want to talk about this matter anymore as she has been crushed inwardly like King Lear (a character in the Shakespearean play 'King Lear' who has been shattered because of his daughters' unbearable conduct towards their father). Ujala torments his mother as a punishment for Chanda and Jugnu's murder committed by Pakistanis (and she favors Pakistani culture). His use of directive speech act, his insistence, mockery and criticism on both at his mother and her religious and social laws make his culture hybrid.

\subsection{Analysis of Exchange Twenty}

Kaukab leaves the conversation after tiredness but Ujala continues his criticism on both parents this time by flouting the first levels of the maxims of Quantity and Manner. His outspoken manner through the usage of expressive and directive speech acts shows hybridity in his culture. He uses negative words for his parents and comments on his parents' union that "There couldn't have been a more dangerous union than you two" (Aslam, 2012, p. 461) that they have no time for the people surrounding them. He says that their father is busy with government matters while their mother in religious ones (i.e. she cares about the rules and regulations inherited by her forefathers and does not care for the young generations' point of view) and they both do not care about those lying in their feet. Mah-Jabin stops Ujala not to say against their father as he does everything good following all the maxims of Cooperative Principle. Ujala's (who has no sense to talk to his parents and elders) harsh conduct towards his parents indicates his hybrid culture.

\section{Discussion on Findings and Conclusion}

This study of cultural hybridity in hybrid discourse has shown that the characters in the novel have been changed their pure identities and culture because of the cultural amalgamation of characters living in Britain. The analysis of the Cooperative Principle (1975) has revealed that there is no purity in their culture; the fact that the first senses of the maxims of Quantity and Manner frequently violated by the characters suggests that they enjoy a great amount of freedom of speech: they do not afraid of punishment and endeavor to say what they want to speak to make their culture hybrid. The characters do not take their cultural norms into account while addressing one another. It (ibid) has also suggested that the interaction between characters frequently relies on contradiction.

The study of Speech Acts employed by characters, following Searle's model (1976), has made evident that Expressive, directive, representative, commissive and declarative speech acts are often used in the expression of negotiation of hybrid identities and expressive, directive and representative speech acts have been constantly resorted to by characters in order to express ferocity and depression; to question someone's authority, to ask something and to order or request someone; and to justify themselves respectively to participants involved in the negotiation of topic.

Therefore, it is possible to regard the relationship between characters as a relationship built on ambivalent power relations because the frequency of contradiction suggests that there are no fixed prevailing and subjugated roles among the characters (as they change their roles when they flout their culture and lose their identities). In the relationship among characters, conversational power is continually being exchanged in the process of face-to-face interaction. This study of cultural hybridity 
has also demonstrated that characters in Aslam enjoy a lot of license since they have to hybrid their identities and culture and in this way, they perform different roles, sometimes as a dominant and sometimes as dominated.

\section{References}

Abushihab, I. (2015). A Pragmatic Stylistic Framework for Text Analysis.International Journal of Education, 7(1), 110-118.

Adinkrah, M. (2013). Glimpses of African Suicidality: Suicide and Culture in Chinua Achebe's Things Fall Apart and ElechiAmadi'sthe Concubine. European Journal of Social Sciences, 37(1), 21-31.

Ajmal, M. (2014). Stylistics and Discourse Analysis of Swift's on Poetry: A Rhapsody. International Journal of Languages and Literatures, 2(2), 291-295.

Amer, M. P. (2012). KAUKAB IN MAPS FOR LOST LOVERS, BY NADEEM ASLAM: $\quad$ REPRESENTING AND SUBVERTING THE UNSPEAKABILIY OF THE SUBALTERN. ES.Revista de FilologíaInglesa, 33, 253-270.

Antony, F. (2014). Cohesion in conversation: A Discourse Stylistics Approach on Amitav Gosh's Sea of Poppies. International Journal of Science and Research, 3(10), 535-538.

Aslam, N. (2012). Maps For Lost Lovers. United Kingdom: Random House India.

Bayat, N. (2013). A study on the use of speech acts. Procedia-Social and Behavioral Sciences, $70,213-221$.

Bhabha, H.K. (1994). The Location of Culture. London: Routledge.

Calvo, C. (1990). Power Relations and Fool-Master Discourse in Shakespeare: A Discourse Approach to Dramatic Dialogue. (Doctoral Dissertation, University of Nottingham, 1990). Retrieved from http://eprints.nottingham.ac.uk/11387/1/252718

Carter \& Simpson (1989).Language, Discourse and Literature An Introductory Reader in

Discourse Stylistics. London: Routledge.

Crystal, D. (1997). The Cambridge Encyclopedia of Language. Cambridge: Cambridge University Press. Devika, R. (2016). A POSTCOLONIAL STUDY OF ARUNDHATI ROY'S THE GOD OF SMALL THINGS.Research Journal of English Language and Literature, 4(1), 361-367.

Gautam, K. K. (1987). PINTER'S THE CARETAKER A Study in Conversational Analysis. Pragmatics 11, 49-59.

Hassan, N. A. (2010). Conversation Analysis of Forum: a Selected Text from Paul S. Kemp Online Journal. J. Of College Of Education For Women, 21 (4), 966-988.

Karanja, L. (2010). - Homelessll at Home: Linguistic, Cultural, and Identity Hybridity and Third Space Positioning of Kenyan Urban Youth. Education canadienneet international, 39, 1- 11.

Karima, A. (2013). Hybridity and trepidation of multiculturalism in Gabriel Garcia Marquez's Of Love and Other Demons and Joseph Conrad's Heart of Darkness. International Journal of English and Literature, 4(8), 404-407.

Levinson, S. C. (1983). Pragmatics. Cambridge: Cambridge University Press.

Magu, S. (2015).Reconceptualizing Cultural Globalization: Connecting the - Cultural Globalll and the -Cultural Localll Social Sciences, 4, 630-645.

Mashori, G. M. \&Zaib, S. (2015). Subalterns Can Speak: Shahraz's Message of Hope for Human Equality in Zemindar's Wife. ELF Annual Research Journal, 17, $183-196$.

Moore, L. (2009). British Muslim Identities and Spectres of Terror in NadeemAslam'sMaps for Lost Lovers. Postcolonial Text, 5(2), 1-19.

Naranjo, J. M. (2008). WALKING DOWN THE BORDERLINE: HYBRIDITY AND THE OF THE SELF IN THREE CANONICAL CHICANO NOVELS.Odisea, 9, 167-178. 
STUDY OF SELECTED LITERARY TEXTS. International journal of Science Commerce and

Humanities Volume, 2(4), 285-289.

Osisanwo, A. (2013). Politeness Phenomena in Omobowale'S the President'SPhysician.Arts and

Design Studies, 9, 1-13.

Parmar, A. M. (2015). FEMININE ASPECTS IN BAPSI SIDHWA'S THE ICE-CANDY- $\quad$ MAN. Scholarly Research Journal for Humanity Science \& English Language, 2(11), $\quad$ 1910-1915.

Phompun, C., Thongthew, S. \&Zeichner, K.M. (2013).The Use of the Hybridity Theory and the Third

Space Concept to Develop a Teaching Identities Enhancement Program for Student Teachers.Silpakorn University Journal of Social Sciences, Humanities, and Arts, 13(1), 197-213.

Qadha, A. M. H. (2013). How Pragmatics Leads to a Better Interpretation of Poetry: A Discourse Stylistic Study of D.H.Lawrence's Poem "Sorrow". GSTF International Journal on Education, 1(2), 82-86.

Saini, A. K. (2015). Arundhati Roy's The God of Small Things: A Revelation of Feminine Perspectives. International Journal of English Language, Literature and Humanities, 3(10), 393-399.

Shirazi, Q. (2014). Tradition and Modernity in KamilaShamsie's Salt and Saffron (2000). International Journal of Language, Literature and Culture, 1(2), 23-27.

Silima, N. (2013). Subjugation: A study of the women characters in Khalid Hosseini's and

Arundhati Roy's novels. International Journal of English and Literature, 4(10), 456461.

Sinclair, J. M. \&Coulthard, R. M. (1975).Towards an Analysis of Discourse: The English used by teachers and pupils. London: Oxford University Press.

Singh, B. (2015). Articulating the Female Voice: A Gynocentric Critique of the Novels of Bapsi

Sidhwa.International Journal of English Language, Literature and Humanities, 3(10), 364-374.

Waterman, D. (2010). Memory and Cultural Identity: Negotiating Modernity in NadeemAslam's Maps for Lost Lovers. Pakistaniaat: A Journal of Pakistan Studies, 2(2), 18-35.

Weingarten, J.(2011). Traditional Claustrophobia - Intersections of Gender and Religious Identities

in NadeemAslam'sMaps for Lost Lovers. A Postgraduate eJournal for Comparative Literature and Cultural Studies, (1), 1-18.

Yaqin, A. (2013). Cosmopolitan ventures during times of crisis: a postcolonial reading of Faiz Ahmed Faiz's -Dasht-e-tanhailland NadeemAslam'sMaps for Lost Lovers. Pakistaniaat: A Journal of Pakistan Studies, 5(1).

Zaidi, N. A. \&Qureshi, M. B. (2013). Autobiography and woman empowerment with reference to TehminaDurrani's My Feudal Lord. The Women - Annual Research Journal of Gender Studies, $4,1-18$.

Zubair, S. (2012).Crossing Borders, Reinventing Identity (ies): Hybridity in Pakistani English Fiction.Pakistan Journal of Social Sciences, 32(1), 65-75. 